\title{
VANALI, Ana Crhistina. A Erva-mate e a política paranaense: análise da legislação provincial para a economia ervateira (1854-1889). Curitiba: Instituto Memória, 2013.98 p.
}

Natália Cristina Granato ${ }^{1}$

- Enviado em 27/07/2015

- Aprovado em 29/08/2015

A erva-mate tem importância central para a economia paranaense, sobretudo a partir do século XIX. Popularmente conhecida como o "ouro verde" do Paraná, podemos afirmar que esse produto representou um ciclo econômico importante para a formação social e política do estado. Tendo isso em vista, Ana Crhistina Vanali produziu a interessante obra "A erva-mate e a política paranaense", resultado de sua especialização em Sociologia Política pela Universidade Federal do Paraná. Apresentado em 2011, esse estudo foi publicado em livro em 2013, contribuindo decisivamente nas pesquisas sobre a erva-mate no Paraná e abrindo espaço para análises posteriores a partir das ideias que a autora desenvolve no decorrer do livro. Nomes conhecidos na historiografia paranaense, como David Carneiro, Temístocles Linhares, Ruy Wachowicz e Cecília Westphalen abordaram em suas obras considerações sobre a erva-mate. Artigos, monografias e dissertações foram produzidos a respeito do assunto, ou como tema principal em determinados períodos históricos, ou abordando e citando esse assunto. O livro de Ana Vanali se debruça sobre essa produção, trazendo contribuições novas que incrementam o estudo desse ciclo, principalmente no que diz respeito à relação entre a erva-mate e a política paranaense. Sua análise se centra na legislação produzida para a economia ervateira no período provincial do Paraná. Antes de tal análise

\footnotetext{
${ }^{1}$ Graduada em Ciências Sociais pela Universidade Federal do Paraná. Mestranda em Sociologia pela Universidade Federal do Paraná. Endereço eletrônico: nataliagranato@ hotmail.com.
} 
ser feita, a autora percorre a trajetória da erva-mate no Paraná, que oferece a base para as reflexões produzidas.

No capítulo 1, "Economia ervateira paranaense", a autora apresenta um breve histórico do produto, que remonta ao período pré-colombiano, consumido pelos povos "nativos" sem a necessidade de uma produção organizada. A difusão de seu consumo ocorre a partir de 1536 e é intensificada por volta do final do século XVII. A partir disso, a autora elenca as fases da exploração da erva-mate no Paraná. A primeira ocorre entre o final do século XVII e 1830, caracterizado pelo consumo local do mate, com beneficiamento manual realizado por indígenas e escravos na região de Curitiba e Lapa. A segunda fase ocorre entre 1830 e 1870, e caracterizada pela "entrada definitiva do mate paranaense no mercado platino e por transformações qualitativas nos métodos de produção" (p.13). Já a terceira fase, compreendida entre 1870 e 1930, representa um avanço efetivo no preparo industrial do mate, modernizando as técnicas de colheita e beneficiamento com um modelo que preservasse a planta (p.18), aumentando a racionalidade da produção. A erva-mate era o principal produto de exportação do Paraná nesse período.

No capítulo 2, "Aspectos do setor ervateiro", a autora destaca que o apogeu da erva-mate na economia paranaense foi resultado de um longo processo, que se intensificou devido à sua exportação ao mercado platino. Nesse sentido, a fração de classe correspondente ao mate galgou espaços na economia, política e ideologia, se consolidando como classe dominante que investia no aprimoramento de técnicas de beneficiamento, visando o lucro e o acúmulo de capitais. A autora categoriza essa fração como "burguesia do mate", promotora de industrialização e exportação, tendo como referencial teórico Nicos Poulantzas, afirmando que essa fração expressa seus interesses e influencia as práticas do Estado, tornando-se um forte grupo de pressão através de seus porta-vozes nas esferas de poder local. Citando nomes como o Barão do Serro Azul, Visconde de Nacar, Francisco Fontana, Guilherme Xavier de Miranda e Manuel Miró, a autora destaca que tais porta-vozes reivindicavam a atenção das autoridades para os problemas do mate, defendendo interesses específicos da fração de classe (p.31). Ao mesmo tempo, era interesse do Estado manter a economia do mate em expansão, visto que uma das suas principais arrecadações era o imposto sobre as exportações do mate (p.33). Ao encontro da ideia desenvolvida por Nicos Poulantzas, de que o Estado é uma estrutura não separada da luta de classes, a autora destaca que a burguesia do mate disputava os recursos estatais buscando sempre a promoção de seus interesses específicos. Dessa maneira, a análise de políticas públicas é crucial para o entendimento da relação dessa fração de classe em relação ao Estado. Outra informação importante desenvolvida pela autora é a defesa de 
que a economia da erva-mate pode ser considerada como burguesa, levando em consideração a utilização do trabalho livre, a tecnificação da produção e a modernização das forças produtivas com a "subordinação dos trabalhadores e de saberes" (p.43). Essa ideia é também defendida pelos estudos de Francisco Magalhães Filho e Magnus Pereira, autores citados pela autora que se diferenciam das interpretações anteriores que se debruçaram sobre o mate, como os já citados David Carneiro, Cecília Westphalen e Temístocles Linhares.

No capítulo 3, "Diretrizes da implementação das políticas públicas do setor ervateiro na província do Paraná", a autora destaca as reinvindicações do setor ervateiro explorador, em prol da valorização do produto, do valor da erva, do estabelecimento da época de corte, das maneiras de beneficiamento, das punições a falsificadores, da conquista de novos mercados, entre outros. Para a autora, a análise dessas políticas públicas do mate "revelam algumas das formas pela qual essa fração de classe se organizou para fazer prevalecer seus interesses específicos ou como teceram essa possibilidade" (p.65). Para tais considerações, a autora analisou diversas fontes primárias, como leis e políticas públicas produzidas que diziam respeito à erva-mate.

O trabalho é incrementado pelos anexos que a autora inseriu após as conclusões. Vale destacar a rica produção bibliográfica citada pelo trabalho, bem como as possibilidades de novas pesquisas sobre o assunto, pois o texto abre um leque de reflexões e análises importantes para os pesquisadores que se dedicam à compreensão do Paraná e seus aspectos políticos, culturais, históricos, sociais e econômicos. 